\title{
Performance of West African dwarf goats fed Panicum maximum supplemented with Myrianthus arboreus leaf meal concentrates
}

Fajemisin, A. N., Ibhaze, G. A. and Adeyeye, A. A.

Department of Animal Production and Health,

Federal University of Technology, Akure, Ondo State, Nigeria.

Correspondence: begladalways@yahoo.com., gaibhaze@futa.edu.ng

Abstract Tel: +234-8055865289

A feeding trial was conducted to evaluate the performance of West African Dwarf goats fed Panicum maximum supplemented with Myrianthus arboreus leaf meal for 49 days. Four diets were formulated such that diet A contained $0.00 \%$ Myrianthus arboreus, diet B contained $10.00 \%$ Myrianthus arboreus, diet C contained $11.00 \%$ Myrianthus arboreus and diet $D$ contained $12.00 \%$ Myrianthus arboreus respectively. A total of twelve (12) West African Dwarf goats were randomly allocated to the four diets with three animals per diet, each serving as a replicate. Parameters assessed were the chemical composition of the experimental diets, growth rate and digestibility coefficient of the animals. The results showed that diet D had the highest dry matter (92.55\%) and crude protein $(20.55 \%)$ contents. The average daily weight gain (g/day) of animals was significantly $(P<0.05)$ influenced across the treatments. Animals fed diet $D$ recorded the highest weight gain (19.39g/day) while the least weight gain $(7.55 \mathrm{~g} /$ day) was recorded for animals on diet $B$. The highest total dry matter intake (340.34g/day) was recorded for animals on diet $D$ while the least (313.18g/day) was observed in animals fed diet $C$. The best feed conversion ratio (17.55) was recorded in animals fed diet $D$. There were significant differences $(P<0.05)$ in the nutrient digestibility of the experimental animals. The highest dry matter (82.70\%), crude protein (86.18\%) digestibilities were observed in diet $D$ while the least dry matter digestibility (72.73\%) was observed in diet B. However, the least fibre fractions digestibilities were observed in diet $D$. It can therefore be concluded that supplementation of Myrianthus arboreus leaf meal concentrate at 12\% inclusion with Panicum maximum as basal diet for goats can enhance nutrient digestibility and improve growth without any deleterious effects on the animals.

Keywords: digestibility, growth, Myrianthus arboreus, Panicum maximum, goats.

\section{Introduction}

Forages such as grasses and legumes are the main source of feeds for ruminants to meet their nutritional requirements, either for maintenance or production. However, in the tropics, inadequate nutrition is a great challenge contributing to production losses in ruminants (Ibhaze, 2016) due to the unavailability of forages throughout the year. This unpleasant situation has necessitated the search for alternative feed resources rich in energy and protein that are readily available and relatively cheap. These feed resources are incorporated in livestock diets as long as they do not have detrimental effects on the health status and production potentials of the animals (Ibhaze, 2017). In recent times, the use of leaves from multipurpose trees and shrubs as alternative feed resources has gained global recognition. Several indigenous and exotic browse species have been investigated and evaluated for inclusion in ruminant feeding systems in Nigeria (Fajemisin, 2015). Amata (2010) opined that protein from plant leaf sources is perhaps the most naturally abundant and cheapest source of protein, such that there has been growing realization in the use of plant leaf meals in livestock diets. Myrianthus arboreus is a dioecious tropical tree up to $15 \mathrm{~m}$ high with spreading 
branches from a short stem. It is found in forest and damp places and a native of Angola, Cameroon, Congo, Cote d'Ivoire, Democratic Republic of Congo, Kenya, Nigeria, Sudan, Tanzania and Uganda (Orwa et al., 2009). Myrianthus arboreus leaves are a good source of protein $(18.74 \%$ DW), metabolizable energy (1333.4 kcal $\mathrm{kg}^{-1}$ ) minerals and can be used as a supplement in compounding livestock feed, the leaves also contain appreciable level of sulphur containing amino acid and low anti-nutritional components which can be tolerated by most livestock (Amata, 2010).Panicum maximum (Guinea grass) is relished by ruminants especially during the wet season when forages are lush. It contains crude protein $(9-12.5 \%)$, total digestible nutrients (10.2\%), magnesium $(0.06 \%)$ and calcium content of $0.05 \%$ (McDonald et al., 1995). However, during the dry period, these nutrient concentrations decline. Gibson (2007) opined that goats are inquisitive feeders with high efficiency in energy and protein conversion from feeds. This study was therefore designed to investigate the growth and digestibility by West African Dwarf goats fed Panicum maximum supplemented with Myrianthus arboreus concentrate diets.

\section{Materials and methods}

The experiment was conducted at the Small Ruminant Unit of the Teaching and Research Farm, Federal University of Technology, Akure, Ondo state, Nigeria. Akure is located on longitude $4.944055^{\circ} \mathrm{E}$ and $5.82864^{\circ} \mathrm{E}$, and latitude $7.491780^{\circ} \mathrm{N}$ with annual rainfall ranging between $1300 \mathrm{~mm}$ and $1650 \mathrm{~mm}$ average maximum and minimum daily temperature of $38^{\circ} \mathrm{C}$ and $27^{\circ} \mathrm{C}$ respectively (Daniel, 2015). Myrianthus arboreus leaves were harvested within Akure and air dried for seven days and then milled and stored for later use. Four concentrate diets were compounded comprising $0,10,11$ and $12 \%$ levels of inclusion of Myrianthus arboreus leaf meal Twelve (12) WAD bucks with average weight of $5.75 \pm 0.3 \mathrm{~kg}$ were purchased from a reputable source and were randomly assigned to four dietary treatments of three replicates per treatment in a Completely Randomized Design.The goats werehoused in an open - sided, welllighted and adequately ventilated building with concrete floor that had been previously disinfected with germicide. The concrete floor was covered with $5 \mathrm{~cm}$ layers of wood shavings to absorb urine and for easy removal of faeces. An acclimatization period of 14 days was allowed before commencement of the feeding trial. The pens and troughs were cleaned each day before offering feed and water. The animals were fed the experimental diets early in the morning (8.00am) and grass was given in the afternoon $(2.00 \mathrm{pm})$ and cool, fresh drinkable water (ad libitum) was supplied. Left over feed was weighed each morning. Animals' weights were taken using hanging scale at the start of the study, and weekly, throughout the experimental period, and the growth study lasted for forty-nine (49) days. The goats were then transferred to metabolic cages with facilities for separate collection of urine and faeces for digestibility trial. Faeces and urine were collected daily before morning feeding. The urine was collected into plaque bucket placed under each cage and to which few drops of $25 \% \mathrm{H}_{2} \mathrm{SO}_{4}$ was introduced to curtail volatilization of the ammonia from the sample. The daily volume of urine output per goat for a period of 7days was determined and $10 \%$ of daily output was saved in stopper plastic bottles, numbered and stored in a refrigerator at $-5^{\circ} \mathrm{C}$. Samples of feed and faeces were analyzed for proximate and fibre compositions using the method described by AOAC (1990). 


\section{Fajemisin, Ibhaze and Adeyeye}

\section{Statistical analysis}

All data obtained were subjected to one way analysis of variance (ANOVA) of SAS(2012)and significant means were separated using the Duncan's multiple range test of the same package.

\section{Results and discussion}

The gross composition of the experimental diets is presented in Table1. The chemical composition of the experimental diets is shown in Table 2. All the diets had crude protein values adequate for ruminant nutrition. Gatenby (2002) indicated 10-12\% crude protein as requirement for growth of sheep and goats. The high ash content obtained suggests high mineral concentrationsin all the diets. The neutral detergent fibre, acid detergent fibre and acid detergent lignin values ranged from $54.12-59.71 \%, 32.08-36.16 \%$, 25.52$27.80 \%$ respectively. The high fibre fraction in the diets is an indication that the diets are adequate in fibre necessary for proper rumen function.

Table 1: Gross composition (\%) of experimental diets

\begin{tabular}{lllll}
\hline \multirow{2}{*}{ Ingredients } & \multicolumn{4}{c}{ Diets } \\
\cline { 2 - 5 } & $\mathrm{A}$ & $\mathrm{B}$ & $\mathrm{C}$ & $\mathrm{D}$ \\
& $0 \%$ & $10 \%$ & $11 \%$ & $12 \%$ \\
\hline Maize Offal & 47.00 & 47.00 & 47.00 & 47.00 \\
Rice bran & 27.00 & 27.00 & 27.00 & 27.00 \\
Palm kernel cake & 22.00 & 12.00 & 11.00 & 10.00 \\
M. arboreus & 0.00 & 10.00 & 11.00 & 12.00 \\
Urea & 1.00 & 1.00 & 1.00 & 1.00 \\
Bone meal & 2.00 & 2.00 & 2.00 & 2.00 \\
Salt & 1.00 & 1.00 & 1.00 & 1.00 \\
\hline
\end{tabular}

Table 2: Chemical composition (\%) of the experimental diets and Panicum maximum

\begin{tabular}{lllll}
\hline & $\mathrm{A}$ & $\mathrm{B}$ & $\mathrm{C}$ & $\mathrm{D}$ \\
Parameters & $0 \%$ & $10 \%$ & $11 \%$ & $12 \%$ \\
\hline Dry matter & 91.33 & 91.91 & 91.34 & 92.55 \\
Crude protein & 19.17 & 19.03 & 19.12 & 20.55 \\
Crude fibre & 9.23 & 10.79 & 10.68 & 13.08 \\
Ether extract & 11.01 & 12.62 & 11.74 & 11.94 \\
Ash & 12.33 & 11.18 & 12.14 & 13.97 \\
Nitrogen free extract & 48.26 & 46.38 & 46.32 & 40.46 \\
Neutral detergent fibre & 54.12 & 59.71 & 56.53 & 58.50 \\
Acid detergent fibre & 36.15 & 34.18 & 32.08 & 38.44 \\
Acid detergent lignin & 25.04 & 25.52 & 24.65 & 27.80 \\
Hemicellulose & 17.97 & 25.53 & 24.45 & 20.06 \\
Cellulose & 11.11 & 8.66 & 7.43 & 7.74 \\
\hline \hline
\end{tabular}

Growth performance is revealed in Table 3. Significant $(\mathrm{p}<0.05)$ differences were observed in the average daily weight gain and the feed conversion ratio. Total intake by the animals ranged from 313.18 $340.34 \mathrm{~g} /$ day). These values were comparable to the range $(291.55-313.42$ $\mathrm{g}$ /day) reported for WAD goats fed cassava peels-cassava leaf meal based diets (Ukanwoko et al., 2009). Ahamefule and Elendu (2010) opined that factors affecting feed intake include dietary crude protein, palatability, gut fill, rumen outflow rate/retention time in the rumen. Nutrient intake is the most important determinant of an animal's performance There were significant $(p<0.05)$ differences in the average daily weight gain and the feed conversion ratio which ranged from 7.55$19.39 \mathrm{~g} /$ day and $16.55-43.84$ respectively. Animals on diet D ( $12 \%$ inclusion) had the highest average daily weight gain 
WAD goats fed Panicum maximum supplemented with Myrianthus arboreus leaf meal concentrates

(19.39g/day) and the least (17.55) feed conversion ratio. These values are lower than the range of $35.72-64.29 \mathrm{~g} /$ day reported by Ogunbosoye et al. (2016) for West African dwarf goats fed graded levels of shea nut (Vitellaria paradoxa) cakebased rations.

Table 3: Growth performance by West African d warf goats fed experimental diets

\begin{tabular}{|c|c|c|c|c|c|}
\hline \multirow[b]{3}{*}{ Parameters } & \multicolumn{4}{|c|}{ Diets } & \multirow[b]{3}{*}{ \pm SEM } \\
\hline & A & B & $\mathrm{C}$ & $\mathrm{D}$ & \\
\hline & $0 \%$ & $10 \%$ & $11 \%$ & $12 \%$ & \\
\hline Average Initial weight (kg) & 6.03 & 6.03 & 5.20 & 5.75 & 0.13 \\
\hline Average Final Weight (kg) & 6.63 & 6.40 & 5.70 & 6.70 & 0.19 \\
\hline Average daily weight gain (g/day) & $12.24^{\mathrm{b}}$ & $7.55^{\mathrm{c}}$ & $10.20^{\mathrm{bc}}$ & $19.39^{\mathrm{a}}$ & 1.53 \\
\hline Concentrate intake(g/day) & 206.33 & 193.30 & 186.38 & 210.17 & 10.41 \\
\hline Panicum maximum intake(g/day) & 131.83 & 137.70 & 126.80 & 130.71 & 4.62 \\
\hline Total intake (g/day) & $338.16^{\mathrm{a}}$ & $331.00^{\mathrm{ab}}$ & $313.18^{b}$ & $340.34^{\mathrm{a}}$ & 12.72 \\
\hline Feed conversion ratio & $27.75^{\mathrm{b}}$ & $43.84^{\mathrm{a}}$ & $30.70^{\mathrm{b}}$ & $17.55^{\mathrm{c}}$ & 5.92 \\
\hline
\end{tabular}

The nutrient digestibility of the experimental diets by the West African dwarf goats is presented in Table 4. The highest dry matter digestibility was observed in diet D. Bakshi and Wadhwa (2004) reported that high neutral detergent fibre and acid detergent lignin depress dry matter intake and dry matter digestibility. This therefore suggests that the fibre content of the diets was adequate to promote intake and digestibility. The dry matter digestibility obtained in this study was higher than the range of 43.05-50.04\% reported by Ibhaze et al. (2014) for West African dwarf goats fed ensiled mixtures of corncobs, cassava peels and brewers' grain. The crude protein digestibility was higher than the range of $56.2-63.10 \%$ reported by Olorunnisomo (2010) for lambs fed cooked or fermented cassava-urea meal. Fibre is important in the diet of farm animals and some level of fibre enhances proper bowel movement (Odoemelam and Ahamefule, 2006). The crude fibre digestibility values ranged between 76.27$86.18 \%$. This was probably so because the rumen micro-organism were able to effectively digest the nature of fibre in the diets. This observation were comparable with $78.40-80.62 \%$ reported by Maigandi and Abubakar (2004) for Red Sokoto goats fed diets containing graded levels of Faidherbia albizia pod. The ether extract digestibility $(73.25-84.81 \%)$ obtained in this study is similar to the values reported for WAD bucks fed mucuna seed meal and P. maximum (Ukpabi, 2007) and Kano brown goats fed graded levels of rice milling waste (Nayawo et al.,2010).

Table 4: Apparent nutrient digestibility (\%) of West African dwarf goats fed experimental diets

\begin{tabular}{llllll}
\hline & \multicolumn{5}{c}{ Diets } \\
\cline { 2 - 5 } Parameters & $\mathrm{A}$ & $\mathrm{B}$ & $\mathrm{C}$ & $\mathrm{D}$ & \\
& $0 \%$ & $10 \%$ & $11 \%$ & $12 \%$ & SEM \\
\hline Dry matter & $80.69 \mathrm{ab}$ & 72.73 & $77.16 \mathrm{bc}$ & $82.70 \mathrm{a}$ & 1.32 \\
Crude protein & $86.10^{\mathrm{a}}$ & $77.19^{\mathrm{b}}$ & $86.14^{\mathrm{a}}$ & $86.18^{\mathrm{a}}$ & 1.30 \\
Crude fibre & $85.85^{\mathrm{a}}$ & $76.27^{\mathrm{b}}$ & $81.98^{\mathrm{a}}$ & $86.18^{\mathrm{a}}$ & 1.34 \\
Ether extract & $80.71^{\mathrm{ab}}$ & $73.25^{\mathrm{c}}$ & $77.67^{\mathrm{bc}}$ & $84.81^{\mathrm{a}}$ & 1.44 \\
Neutral detergent fibre & $86.44^{\mathrm{a}}$ & $79.54^{\mathrm{b}}$ & $81.42^{\mathrm{b}}$ & $75.07^{\mathrm{c}}$ & 1.27 \\
Acid detergent fibre & $83.28^{\mathrm{ab}}$ & $86.48^{\mathrm{a}}$ & $79.73^{\mathrm{bc}}$ & $78.71^{\mathrm{c}}$ & 1.06 \\
Acid detergent lignin & $80.78^{\mathrm{a}}$ & $81.26^{\mathrm{a}}$ & $71.13^{\mathrm{b}}$ & $71.92^{\mathrm{b}}$ & 1.55 \\
Hemicellulose & $86.29^{\mathrm{a}}$ & $87.03^{\mathrm{a}}$ & $83.84^{\mathrm{b}}$ & $79.22^{\mathrm{c}}$ & 0.96 \\
Cellulose & 91.52 & 91.11 & 88.32 & 86.35 & 0.98 \\
\hline a,b,c = means within the same row with different superscripts are significantly different $(\mathrm{P}<0.05)$
\end{tabular}


Fajemisin, Ibhaze and Adeyeye

\section{Conclusion}

From the result of the study, it can be concluded that Myrianthus arboreus leaf meal possesses adequate nutritive value to support good growth of West African Dwarf goats, especially during the period of drought and the forage can effectively serve as alternative feed ingredient in West African dwarf goats diets with inclusion level of up to $12 \%$ without any deleterious effect. The authors therefore suggest that further research should be carried out using Myrianthus arboreus at higher levels of inclusion in the diets of goats and other livestock to substantiate its suitability and utilization by the animals

\section{References}

A.O.A.C. 1990. Association of Official Analytical Chemist. Official methods of analysis, 15 th Ed.Washington D. C. United States of America.

Ahamefule, F. O. and Elendu, C. 2010. Intake and digestibility of WAD bucks fed cassava leaf-maize offal based diet. Journal of Animal Veterinary, 9: 535-539.

Amata, I. A. 2010. Nutritive Value of the leaves of Myrianthus arboreus: A Browse plant. International Journal of Agricultural Research, 5:576-581.

Bakshi, M. P. S. and Wadhwa, M. 2004. Evaluation of forest leaves of semihilly arid region as livestock feed. Asian-Australasian Journal of Animal Science, 95:93-104.

Daniel, O.A. 2015. Urban extreme weather challenge for healthy living environment Akure Ondo state, Nigeria climate 3(4):775-791.

Fajemisin, A. N. 2015. Chemical composition and in vitro evaluation of the nutrient content of Panicum maximum-Moringa oleifera diets.
Nigerian Journal of Animal Production 42(2):197-208.

Gatenby, R. M. 2002. Sheep Revised Edition-Tropical Agricultural Series. MacMillan Publishers Ltd. Pp. 8.-9

Gibson, A. T. 2007. Meet goat breeds and breeding plans. Agricul;tural Research Services United States Department of Agriculture. (htpp://aq.goat world .com/htm)

Ibhaze, G. A. 2016. Reproductive performance of intensively mamagedprimiparous gravid West African Dwarf goats fed pulverized bio-fibre waste-based diets. Nigerian Journal of Animal Production 43(2):133-138.

Ibhaze, G. A., Babayemi, O. J. and Olorunnisomo, O. A. 2014. Acceptability and digestibility of ensiled mixtures of corncobs, cassava peels and brewers' grain by West African dwarf goats. Nigerian Journal of Animal Production. 41(2): $139-145$.

Ibhaze, G. A. 2017. Influence of hydrothermal treatment duration on the nutritional quality of avocado pear (Persia americana) seed meal for livestock feeding. Animal Research International 14(2):2759-2763

Maigandi, S. A. and Abubakar, S. 2004. Nutrients Intake and Digestibility by Red Sokoko goat fed varying levels of faidherbiaalbida(Acacia) Pods. Proc, $39^{\text {th }}$ Annual Conference Nigeria society of Animal Production. Pp 325-328.

McDonald, P., Edward, R. A., Grenhalgh, J. F. D. and Morgan, C. A. 1995. Animal Nutrition. $5^{\text {th }}$ edition. Pearson Educational Limited, Edinburg gate, 9arlow Essex CM20 2JE, United 
Kingdom.

Nayawo, A. A., Maigandi, S. A. and Muhammed, 2010. Nutrient digestibility by Kano Brown goat fed graded levels of rice milling waste as a replacement for wheat offal. Proc $35^{\text {th }}$ Conference society for Animal production $14^{\text {th }}-17^{\text {th }}$ March 2010, University of Ibadan Pp. 612-614

Odoemelam, V. U. and Ahamefule, F. O. 2006. Effect of De-Hulling on Proximate Compositions, AntiNutritional Properties and Mineral Content of Canavaliapl agiosperma. Tropical Journal of Animal Production, 31 (2): 167175.

Ogunbosoye, D. O., Tona, G. O., Akinfemi, A. and Ajani, M. R. 2016. A preiliminary study on nutrient digestibility by West African dwarf goats fed graded levels of shea nut (Vitellaria paradoxa) cake- based rations. Nigerian Journal of Animal Production 43(2):116-123
Olorunnisomo, O.A. 2010. Sweet potatoes as a ruminants feed. Performance of sheep Fed mixture of the forage and root. Nigeria Journal of Animal Production.35(2): 242-251.

Orwa, C. A., Mutua, K. R., Jamnadass, R. S. A. 2009. Agroforest tree Database:a tree reference and s e le c tionguideversion .http://www.worldagroforestry.or $\mathrm{g} / \mathrm{sites} /$ treedbs/treedatabases.asp)

Statistical Analytical Systems, 2012. SAS Version 9.2 user's guide. Cary, NY: SAS institute.

Ukanwoko, A. I., Ahamefule, F. O. and Ukachukwu, S. N. 2009. Nutrient intake and digestibility of West African Dwarf bucks fed cassava peel-cassava leaf meal based diets in South Eastern Nigeria. Pakistan Journal of Nutrition, 8 (7): 983 987

Ukpabi, U.H. 2007. Evaluation of Mucuna seed meal based diet for goat production in South Eastern Nigeria $\mathrm{PhD}$ dissertation. Michael Okpara University of Agriculture Umudike Nigeria.

Received: $16^{\text {th }}$ November, 2017

Accepted: $21^{\text {st }}$ February, 2018 